\title{
Penerapan Plastic Deposit Refund System Sebagai Instrumen Penanggulangan Pencemaran Limbah Plastik Di Wilayah Perairan Indonesia
}

\author{
Oleh: Irawati Puteri, ${ }^{1}$ Rizkina Aliya, ${ }^{2}$ Satria Afif Muhammad ${ }^{3}$
}

\begin{abstract}
Abstrak
Sebagai poros maritim dunia, perairan dan laut Indonesia merupakan instrumen fundamental sebagai pemberi kehidupan bagi ekosistem, ekonomi, dan masyarakat secara luas. Namun keberlanjutan kualitas perairan dan laut yang memiliki fungsi strategis tersebut rentan oleh pencemaran plastik. Limbah plastik kian menjadi suatu ancaman non-tradisional (non-traditional threat) terhadap keberlangsungan lingkungan hidup perairan Indonesia. Pada tahun 2015, penelitian oleh Jenna Jamback menemukan bahwa 3,2 juta ton limbah plastik mencemari perairan Indonesia, menjadikan Indonesia sebagai sumber limbah plastik laut terbesar di Asia Tenggara dan terbesar kedua di dunia (dengan Republik Rakyat Cina menempati posisi nomor satu). Indonesia membutuhkan suatu rencana kebijakan praktis untuk menanggulangi pencemaran limbah plastik di wilayah perairannya; oleh karena itu, makalah ini membahas upaya penerapan plastic deposit refund system terhadap produk-produk plastik sebagai suatu diversifikasi solusi alternatif yang dapat efektif mengurangi laju pencemaran limbah plastik di lautan berdasarkan prinsip perluasan tanggung jawab (extended producer responsibility).

1 Penulis adalah Mahasiswa Program Sarjana di Fakultas Hukum Universitas Indonesia, dapat dihubungi melalui surel: irawati.puteri@ui.ac.id.

2 Penulis adalah Mahasiswa Program Sarjana di Fakultas Hukum Universitas Indonesia, dapat dihubungi melalui surel: rizkina.aliya@ui.ac.id.

3 Penulis adalah Mahasiswa Program Sarjana di Fakultas Hukum Universitas Indonesia, dapat dihubungi melalui surel: satria.afif@ui.ac.id.
\end{abstract}


Kata kunci: Limbah plastik, perairan Indonesia, plastic deposit refund system,

\begin{abstract}
As the maritime axis of the world, the waters and seas of Indonesia are fundamental instruments to support the ecosystem, economic, and society; however, the sustainability of marine environment is vulnerable to plastic contamination. Plastic waste has become a pressing non-traditional threat to the environmental sustainability of Indonesia's marine environment. By 2015, research done by Jenna Jamback found that 3.2 million tons of plastic waste has contaminated Indonesian waters, making Indonesia the largest contributor of marine plastic waste in Southeast Asia and the second largest in the world. Indonesia urgently needs a practical policy plan to tackle the pollution of plastic debris in its marine environment; therefore, this paper discusses the application of a plastic deposit refund system for plastic products as an economic instrument that can effectively reduce the rate of plastics pollution in the ocean based on the concept of extended producer responsibility.
\end{abstract}

Keywords: Plastic waste, Indonesian waters, non-traditional threats, plastic deposit refund system

\title{
I. Pendahuluan
}

"Bernegara hukum untuk apa? Bernegara hukum untuk membahagiakan rakyat." - Prof. Satjipto Rahardjo.

Determinasi untuk menggapai kebahagiaan rakyat diejawantahkan secara afektif dalam sendi mulia tujuan negara maupun penjaminan hak-hak asasi manusia dalam konstitusi. Secara philosophische grondslag, staatsfundamentalnorm Indonesia yakni Pembukaan Undang-Undang Dasar Negara Republik Indonesia Tahun 1945 menghendaki pemajuan kesejahteraan umum dan perlindungan terhadap segenap bangsa Indonesia. Pengejawantahan secara konkrit dan konstruktif dari hal ini dalam konteks lingkungan hidup salah satunya adalah penjaminan hak asasi manusia akan lingkungan hidup yang sehat sebagaimana tertuang dalam Pasal 
28H ayat (1) Undang-Undang Dasar Negara Republik Indonesia 1945 sebagai staatsgrundgezet. Pasal 28H ayat (1) UUD 1945 berbunyi “Setiap orang berhak hidup sejahtera lahir dan batin, bertempat tinggal, dan mendapatkan lingkungan hidup yang baik dan sehat serta berhak memperoleh pelayanan kesehatan." ${ }^{4}$

Jika ditilik lebih lanjut, sejatinya konstruksi pasal 28 H UUD NRI 1945 mencerminkan gagasan ekokrasi dalam paradigma hak asasi manusia dan memberikan basis konstitusional bagi konstitusi hijau (green constitution).

Menurut Prof. Jimly Asshidiqqie doktrin demokrasi yang bersifat anthroposentris harus diseimbangkan dengan ekokrasi yang bersifat ekosentris. Paham antroposentrisme harus berada dalam posisi hubungan yang saling imbang-mengimbangi (checks and balances) dengan paham ekosentrisme. Paham ini mengimani bahwa alam semesta ini merupakan suatu kesatuan sistim yang saling berhubungan dan saling bergantung sama sama lain dan tidak berada pada posisi subordinatif. Alam kehidupan merupakan suatu kesatuan ekosistem. Oleh karena itu, paradigma berpikir manusia harus berubah dari "anthroposentris" ke "theosentrisme" sampai ke titik keseimbangan (equilibrium) dan menyadari pentingnya "ekosentrisme". ${ }^{5}$

Sejalan dengan paham ekosentrisme, Prof. Jimly Asshidiqqie mengintrodusir gagasan konstitusi hijau, yakni melakukan konstitusionalisasi norma hukum lingkungan dengan menaikkan derajat norma perlindungan lingkungan hidup ke tingkat konstitusi. Dengan demikian, pentingnya prinsip pembangunan berkelanjutan yang berwawasan lingkungan dan perlindungan terhadap lingkungan hidup memiliki pijakan kuat dalam peraturan perundang-undangan. Atas dasar itu, konstitusi hijau secara aspiratif turut menekankan pentingnya kedaulatan lingkungan.

Dengan demikian merujuk pada landasan filosofis yakni Pasal $28 \mathrm{H}$ ayat (1) Undang-Undang Dasar Negara Republik Indonesia Tahun 1945, norma perlindungan lingkungan hidup di Indonesia sebetulnya telah memiliki pijakan yang cukup kuat. Namun, diseminasi gagasan konstitusi hijau yang mengusung urgensi penegakkan hak atas lingkungan hidup perlu digalakkan.

4 Undang-Undang Dasar Negara Republik Indonesia Tahun 1945, Pasal 28H ayat (1)

5 Jimly Asshidiqie, "Demokrasi dan Ekokrasi", http://www.jimly.com/makalah/namafile/160/Demokrasi_dan_Ekokrasi.pdf diakses 1 Desember 2017 
Dalam tulisan ini, berangkat dari refleksi akan hak atas lingkungan hidup yang sehat, yang merupakan bagian dari hak asasi manusia yang telah menjadi tanggung jawab Negara dalam memenuhinya, Penulis akan membahas upaya pengejawantahan kedaulatan lingkungan pada permasalahan pengelolaan limbah plastik melalui perumusan salah satu instrumen kebijakan lingkungan hidup yakni instrumen ekonomi lingkungan hidup. Internalisasi eksternalitas biaya lingkungan dalam produksi barang yang akrab dalam lalu lintas keseharian masyarakat Indonesia akan dirangkum dalam suatu deposit refund system berkaitan dengan pengelolaan limbah plastik, secara spesifik yakni botol-botol kemasan plastik. Secara yuridis normatif, tinjauan proyeksi efektivitas deposit refund system dalam pengelolaan limbah plastik juga akan diuji dengan teori Friedman yakni efektivitas sistem hukum dengan bercermin pula pada status quo upaya pengelolaan sampah dan perlindungan lingkungan hidup di Indonesia. Secara garis besar, tulisan ini dapat didikotomikan menjadi pembahasan deposit refund system sebagai instrumen ekonomi penataan hukum lingkungan dan kajian proyektif implementasi deposit refund system yang melibatkan unsur pemerintah, swasta, dan masyarakat dengan teori efektivitas sistem hukum oleh Lawrence M. Friedman sebagai batu uji dalam penerapan deposit refund system.

\section{Status quo Permasalahan Plastik Indonesia}

Permasalahan sampah di Indonesia mulai menggugah nurani dan logika pada saat terjadinya tragedi longsor sampah di Tempat Pembuangan Akhir (TPA) Leuwigajah. Problematika penimbunan sampah di TPA Leuwigajah yang semakin hari semakin menggunung ditambah dengan manajemen pengelolaan sampah yang buruk, berhilir pada longsornya TPA Leuwigajah setelah diguyur hujan deras secara konstan selama 3 hari berturut-turut. ${ }^{6}$ Tepat jam 02:00 pagi tanggal 21 Februari 2005, 27 juta $\mathrm{m}^{3}$ sampah mengubur 3 kampung di bawahnya, yang setidaknya menyebabkan ${ }^{7} 141$ orang meninggal dunia, 6 orang luka berat, kerugian

6 Amelia Hastuti, “Tragedi Longsor TPA Leuwigajah Harus Jadi Cambuk bagi Masyarakat Agar Peduli Sampah", http://rri.co.id/post/berita/363673/feature/tragedi_longsor_tpa_ leuwigajah_harus_jadi_cambuk_bagi_masyarakat_agar_peduli_sampah.html diakses 28 November 12:15 WIB.

7 Kementerian Lingkungan Hidup dan Kehutanan, Surat Edaran tentang Pelaksanaan Peringatan Hari Peduli Sampah Nasional (HPSN) Tahun 2017, Surat Edaran Nomor SE.1/MenLHK-SetJen/ Rokum/PLB.3/1/2017, hlm. 1. 
materiil mencapai 65 miliar dan pembebasan 68 rumah pada lahan 12 hektar yang tertimbun longsor di sekitar TPA Leuwigajah dengan biaya mencapai Rp 15 Miliar. Tragedi naas ini menjadi tamparan keras bagi Pemerintah Indonesia dan kemudian menjadi Hari Peduli Sampah Nasional yang diperingati setiap tanggal 21 Februari setiap tahunnya.

Menggunungnya sampah di Indonesia secara dramatis setiap tahun menjadi suatu konsekuensi logis sebagai akibat dari jumlah manusia yang terus bertambah, aktivitas dan gaya hidup yang makin praktis, dan tingkat konsumsi masyarakat yang naik secara signifikan. Hal ini diperparah dengan rendahnya kesadaran masyarakat mengenai persoalan sampah, buruknya pengelolaan sampah di berbagai TPA, serta norma hukum yang belum tepat sasaran dan efektif menjadikan problematika terkait pengelolaan sampah kerap dianggap sebagai permasalahan yang tak kunjung terpecahkan. ${ }^{8}$

Dalam perkembangannya, permasalahan sampah terutama sampah plastik di Indonesia kian kompleks saat sampah plastik ini menyentuh air, laut dan samudera kita. Tamparan telak bagi Indonesia dirasakan saat dipublikasikannya hasil penelitian oleh Jenna R. Jambeck yang berjudul Platic Waste Inputs from Land into the Ocean dan menyatakan bahwa potensi sampah plastik yang ada di lautan Indonesia pada tahun 2015 mencapai 187,2 juta ton/ tahun. ${ }^{9}$ Statistik ini memboyong piala bagi Indonesia menjadi Negara kedua terbesar di dunia yang menyumbang sampah ke laut setelah Cina yang menduduki peringkat pertama. ${ }^{10}$ Sampah plastik laut (marine plastic debris) adalah aktor pencemar laut yang merupakan ancaman serius bagi kehidupan ekosistem dalam laut. Sampah plastik laut merupakan substansi padat yang diproduksi atau diproses secara langsung atau tidak langsung, sengaja atau tidak sengaja, dibuang atau ditinggalkan di dalam lingkungan laut. ${ }^{11}$ Sebagian besar dari sampah plastik laut ini merupakan hasil dari kegiatan antropogenik (manusia), dimana rata-rata $20 \%$ sampah plastik yang dibuang di daratan akan menemukan jalannya menuju perairan, baik itu sungai maupun lautan. ${ }^{12}$ Namun

8 Hartuti Purwaeni, “Bom Waktu Sampah”, Suara Merdeka (Februari 2017), hlm. 1.

9 Jambeck, J.R., Andrady, A., Geyer, R., Narayan, R., Perryman, M., Siegler, T., Wilcox, C., Lavender Law, K., “Plastic waste inputs from land into the ocean”, Science, 347 (2015), p. 768-771.

10 Ibid.

11 Akbar Tahir, "Anthropogenic Debris in Seafood", Departemen Ilmu Kelautan Fakultas Ilmu Kelautan dan Perikanan Universitas Hasanuddin, hlm. 2.

12 Ibid., hlm. 3. 
angka 20\% ini dapat meningkat tajam di Indonesia mengingat Indonesia adalah negara perairan yang memiliki jumlah sungai, danau, laut dan samudera yang lebih besar dibanding negara-negara lain di dunia. ${ }^{13}$ Sehingga angka probabilitas bertemunya sampah plastik daratan ke daerah perairan menjadi jauh lebih tinggi daripada di negara-negara lain pula.

Plastik memang menjadi salah satu bahan yang paling penting, praktis, dan populer dengan beragam kebutuhan di dunia. Penggunaannya sendiri telah meningkat 20 kali lipat dalam waktu 50 tahun ke belakang ini dan diprediksi akan meningkat sebanyak dua kali lipat dalam 20 tahun ke depan. ${ }^{14}$ World Economic Forum dalam laporannya yang berjudul "The New Plastics Economy: Rethinking the future of plastics" mengatakan bahwasanya pada tahun 2050, rasio perbandingan antara plastik dan ikan akan mencapai 1:1. ${ }^{15}$ Tentu, jika Indonesia tidak bergerak menyelesaikan permasalahan kronis ini secara progresif dan komprehensif, bukan tidak mungkin beberapa tahun ke depan kita akan menggusur tempat Cina untuk menyandang status poluter sampah plastik terbesar dunia.

\section{Deposit Refund System sebagai Instrumen Ekonomi Penaatan Hukum Lingkungan}

Penanganan permasalahan plastik di perairan Indonesia berkaitan erat dengan penaatan atas hukum lingkungan oleh produsen maupun konsumen produk-produk plastik sebagai pencemar. Penegakan yang dulunya ekslusif berada di tangan pemerintah dalam bentuk atur dan awasi dapat dipandang sebagai upaya yang kurang komprehensif untuk menanggulangi permasalahan yang menyangkut berbagai pemangku kepentingan pasar.

Generasi kedua dari pendekatan penegakan hukum lingkungan adalah marketbased approach melalui penggunaan instrumen-instrumen ekonomi. Instrumen

13 Departemen Kelautan dan Perikanan Sekretaris Jendera Satuan Kerja Dewan Maritim Indonesia., "Evaluasi Kebijakan dalam Rangka Implementasi Konvensi Hukum Laut Internasional (UNCLOS 1982) di Indonesia", (DKP: Jakarta, 2008), hal. 2.

14 Ivan, “Sampah plastik diprediksi penuhi lautan pada 2050", https://beritagar.id/artikel/ sains-tekno/sampah-plastik-diprediksi-penuhi-lautan-pada-2050 diakses pada 28 November 2017.

15 World Economic Forum, "The New Plastics Economy: Rethinking the future of plastics", World Economic Forum (2016), hlm. 14. 
ekonomi bertujuan untuk mempengaruhi pasar secara artifisial agar setiap pelaku terdorong untuk mempertimbangkan biaya pencemaran. ${ }^{16}$ Instrumen ekonomi juga menjadi suatu komponen yang penting dalam pendekatan refleksif sebagai perkembangan penataan generasi berikutnya selain daripada komponen instrumen sukarela, keterbukaan informasi publik, sertifikasi oleh pihak ketiga, partisipasi pengelolaan lingkungan oleh kelompok kepentingan, dan prosedur bagi pelembagaan refleksi dan kritik diri. ${ }^{17}$

Instrumen ekonomi adalah manifestasi dari penerapan prinsip pencemar membayar (polluter pays principle) yang merupakan sebuah kebijakan ekonomi untuk menginternalisasi biaya-biaya pencemaran atau kerusakan lingkungan (eksternalitas). Untuk dapat menerapkan instrumen ekonomi, pemerintah tetap harus berperan, secara khusus karena telah terjadi suatu kegagalan pasar $^{18}$ dalam bentuk adanya perbedaan antara biaya marjinal dari produksi swasta dengan biaya marjinal dari eksternalitas sosial. Eksternalitas terjadi saat pasar gagal mempertimbangkan total biaya dari proses produksi yang termasuk biaya-biaya pencemaran dan kerugian yang harus ditanggung oleh lingkungan dan masyarakat (social costs) dan hanya menghitung biaya pribadi produsen (private costs). ${ }^{19}$

Salah satu manifestasi dari prinsip pencemar membayar adalah adanya extended producer responsibility. Konsep extended producer responsibility berarti bahwa produsen bertanggung jawab atas setiap tahap produksi yang dilakukan, dimulai dari awal rantai produksi dengan desain produk sampai post-comsumer phase. Dengan adanya perluasan tanggung jawab tersebut diharapkan dapat mengurangi beban kepada negara untuk memproses limbah yang dihasilkan dengan cara mengurangi jumlah limbah melalui peningkatan daur ulang. ${ }^{20}$ Realisasi dari konsep

16 Eric W. Orts, Reflexive Environmental Law, “Northwestern University Law Review”, Vol. 89, 1995a, hal. 1242. Sebagaimana dikutip dari Andri Wibisana (2014, October). Prinsip-Prinsip Hukum Lingkingan. Depok, Indonesia: Fakultas Hukum Universitas Indonesia.

17 Eric W. Orts, A Reflexive Model of Environmental Regulation, "Business Ethics Quarterly", Vol. 5(4), Oct., 1995b, hal. 788. Sebagaimana dikutip oleh Andri Wibisana (2014, October). Prinsip-Prinsip Hukum Lingkingan. Depok, Indonesia: Fakultas Hukum Universitas Indonesia.

18 Andri G. Wibisana, “Campur Tangan Pemerintah Dalam Pengelolaan Lingkungan: Sebuah Penelusuran Teoretis Berdasarkan Analisis Ekonomi atas Hukum (Economic Analysis of Law), Jurnal Hukum \& Pembangunan 47 No. 2 (2017): 151-182, hlm. 157

19 Robert S. Pindyck dan Daniel L. Rubinfeld, “Microeconomics", (Prentice Hall, 2001), hal. 592

20 OECD, Extended Producer Responsibility: Guidance for efficient waste management, (Paris: OECD Pubishing, 2016), hlm.1 
tersebut yang dapat menguntungkan bagi produsen, konsumen, dan negara adalah penerapan sistem pengembalian deposit atas produk plastik sekali pakai.

Sistem pengembalian deposit (deposit refund system) adalah suatu bentuk instrumen ekonomi di mana seseorang harus membayar di muka sejumlah uang untuk menjamin bahwa ia tidak akan melakukan pencemaran atau bahwa dia akan melakukan suatu kewajiban, fungsinya adalah untuk memfasilitasi pengembalian produk (product take-back). ${ }^{21}$ Jika kewajiban tersebut telah dilakukan, maka uang jaminan tersebut akan dikembalikan. Sistem pengembalian deposit memungkinkan tingkat pengumpulan kembali yang tinggi dari material produk yang berpotensi menjadi pencemar lingkungan seperti plastik dengan kualitas bahan yang masih tetap terjaga untuk mempermudah daur ulang dan menurunkan kebutuhan penggunaan bahan mentah yang harus diekstraksi kembali dari sumber daya alam. Selain meningkatkan pengumpulan kembali produk-produk plastik dan tingkat daur ulang, penerapan deposit-refund system diharapkan dapat mendorong perbaikan terhadap pengolahan limbah dan perbaikan terhadap desain produk. Keuntungan-keuntungan yang didapatkan dari penerapan deposit-refund system yang teratur tersebut pada akhirnya dapat turut mengurangi konsentrasi pencemaran plastik di perairan.

Upaya ini telah dilakukan oleh berbagai negara termasuk Jerman dan Swedia yang menerapkan sistem one-way deposit di mana kemasan plastik sekali pakai dapat diambil kembali oleh produsen dengan pengembalian sejumlah uang kepada konsumen (refund). Di Jerman, distributor dari kemasan plastik yang wajib dilekati nilai deposit diwajibkan untuk menerima kemasan-kemasan gelas, plastik, besi, dan bahan-bahan komposit yang disebarkan ${ }^{22}$. Hasil dari Verpackungsverordnung (Packaging Ordinance) atau Peraturan Pengemasan, di Jerman 98,5\% dari botol-botol kemasan dikembalikan oleh para konsumen sejak negara tersebut mengesahkan legislasi mengenai uang jaminan untuk produk-produk sekali pakai (Einwegpfand) pada tahun 2003. Kualitas dari botol-botol tersebut pun terjaga sehingga botol

21 Yasuhiko Hotta, et.al., eds., Extended Producer Responsibility Policy in East Asia: in Consideration of International Resource Circulation (Japan:Institute for Global Environmental Strategies, 2009), hlm. 5.

22 "Each distributor shall be obliged to accept returned one-way drinks packaging made of such types of materials (glass, plastics, metals, composite material materials) as the distributor supplies in his own product range." DPG-Pfandsystem, "Function of the Deposit-Scheme," http:/ / www.dpgpfandsystem.de/index.php/en/ diakses pada 5 Februari, 2018 
baru kemungkinan besar dapat dibentuk dari botol lama. Deposit refund system Jerman (Deutsch Pfandsystem GmbH atau dikenal sebagai DPG) dibiayai oleh iuran keanggotaan asosiasi berbagai pihak yang terkait dengan produksi dan distribusi single-use containers seperti produsen, distributor, dan kolektor yang dapat berupa retailer yang dikenal oleh masyarakat ${ }^{23}$.

Sedangkan di Swedia, tingkat pengembalian bahan plastik mencapai $77 \%$ sejak pendauran ulang bahan-bahan plastik dan kemasan lain dikelola oleh perusahaan AB Svenska Returpack dengan penerapan Förordning om retursystem för plastflaskor och metallburkar (Ordinance on the Return System for Plastic Bottles and Metal Cans). ${ }^{24}$ Undang-undang tersebut mengatur pemberian insentif untuk meningkatkan pengembalian dan pendauran ulang dari botol-botol plastik serta kaleng aluminium. Tingkat daur ulang yang tinggi atas kemasan-kemasan plastik di negara-negara tersebut dapat membantu mengurangi jumlah sampah plastik yang mencapai laut pada akhir masa pemakaiannya.

Meskipun contoh-contoh global menjanjikan, deposit-refund system bukan suatu obat mujarab bagi semua segala permasalahan yang dibawa oleh pemakaian plastik secara ekses. Di Taiwan, diadakan suatu program depositrefund system untuk botol-botol PET yang dikelola dengan cara para produsen dan importir botol-botol plastik tersebut diwajibkan untuk membayar sejumlah uang untuk kepada suatu recycling fund yang juga menjadi sumber refund bagi konsumen yang mengembalikan kemasan-kemasan botol plastik kepada titik-titik pengembalian. Jumlah uang yang dibayarkan oleh para produsen sesuai dengan proporsi penjualan botol plastik mereka. Meskipun sistem ini serupa dengan yang diterapkan di Jerman, Taiwan menemui beberapa masalah yang mencolok yaitu pengelolaan recycling fund yang ada dan penegakan kewajiban bagi para produsen yang tidak membayar.

Penerapan deposit refund system di Indonesia harus berangkat dari pelajaranpelajaranyangdidapatkandarinegara-negaralaindenganturutmempertimbangkan

23 Anker Andersen, “Deposit system law- Germany," http://anker-andersen.dk/depositlaws/germany.aspx, diakses pada 5 Februari, 2018

24 Zero Waste Europe, “Beverage packaging and Zero Waste," https:// www.zerowasteeurope. eu/tag/germany-deposit-refund-system/ diakses pada 28 November, 2017 Bottle Bill Resource Guide, "Sweden," http://www.bottlebill.org/legislation/world/sweden.htm, diakses pada 7 Februari, 2018 
konteks kerangka hukum lingkungan yang ada serta budaya masyarakat. Jika sistem tersebut diharapkan dapat mengubah status quo pencemaran air oleh limbah plastik di Indonesia, efektivitas dari sistem pengembalian deposit sebagai inisiatif instrumen ekonomi yang baru harus dijamin oleh adanya sistem hukum penopang yang efektif pula.

\section{Teori Efektivitas Sistem Hukum oleh Friedman sebagai Batu Uji dalam Penerapan Deposit Refund System}

Lawrence M. Friedman mengintrodusir "Legal System Theory" yang mensyaratkan adanya pemenuhan akan 3 komponen sistem hukum, yakni substansi hukum, struktur hukum, serta budaya hukum untuk dapat menilai efektifitas suatu sistem hukum..$^{25}$

Substansi hukum berarti produk yang dihasilkan oleh legislator yang berada dalam sistem hukum. Substansi tak terestriksi hanya pada hukum yang tertulis namun juga mencakup hukum yang hidup (living law), bukan hanya aturan yang ada dalam peraturan perundang-undangan. Struktur hukum yakni infrastruktur yang menjamin serta memfasilitasi hukum tersebut berjalan. Selain itu elemen yang ketiga yakni budaya atau kultur hukum. Budaya hukum menurut Friedman adalah sikap manusia terhadap hukum dan sistem hukum. Kultur hukum adalah suasana pemikiran sosial dan kekuatan sosial yang menentukan bagaimana hukum digunakan, dihindari, atau disalahgunakan. Budaya hukum erat kaitannya dengan kesadaran dan kepatuhan hukum masyarakat. Terpenuhinya tiga komponen esensial ini secara paripurna, akan berimplikasi pada terwujudnya suatu sistem hukum yang efektif.

\section{A. Substansi hukum untuk penerapan deposit refund system}

Efektivitas deposit refund system sebagai sebuah instrumen ekonomi diukur melalui parameter yang abstrak dan bersifat kualitatif yakni bagaimana pelaku usaha/kegiatan telah mengubah perilaku atau proses kegiatan mereka menjadi ramah lingkungan untuk menghindari biaya yang mahal, bukan dari seberapa

25 Lawrence M. Friedman, The Legal System: A Social Science Perspective, (New York: Russel Sage Foundation, 1975) 
besar pendapatan negara yang didapatkan oleh penerapan instrumen ekonomi tersebut. Jika merujuk kembali kepada teori legal system dari Friedman maka komponen utama adalah adanya susbtansi (legal substance) yang dapat memfasilitasi penerapan dari deposit refund system.

Pada konteks pengelolaan sampah, yang bertujuan untuk meningkatkan kesehatan masyarakat dan kualitas lingkungan serta menjadikan sampah sebagai sumber daya sebagaimana diamanatkan dalam Undang-Undang Nomor 18 Tahun 2008 tentang Pengelolaan Sampah, ${ }^{26}$ Pemerintah dan pemerintahan daerah bertugas menjamin terselenggaranya pengelolaan sampah yang baik dan berwawasan lingkungan. ${ }^{27}$

Mengejawantahkan secara ekstensif tujuan mulia tersebut, regulasi merumuskan perihal kewajiban produsen yakni, produsen wajib mengelola kemasan dan/atau barang yang diproduksinya yang tidak dapat atau sulit terurai oleh proses alam. ${ }^{28}$ Menilik lebih lanjut, pasal 14 Peraturan Pemerintah Nomor 81 Tahun 2012 tentang Pengelolaan Sampah Rumah Tangga dan Sampah Sejenis Sampah Rumah Tangga secara derivatif turut mengartikulasikan kewajiban produsen untuk melakukan pemanfaatan kembali sampah dengan salah satu cara yakni menarik kembali sampah dari produk dan kemasan produk untuk diguna ulang. Sehingga dapat disimpulkan bahwa 1) produsen wajib mengelola kemasan yang tidak dapat atau sulit terurai oleh proses alam dan 2) produsen wajib melakukan pemanfaatan kembali sampah dengan mendaur ulang kemasan produk. Klausula ini merupakan klausula yang akomodatif terhadap adanya cetusan deposit refund system.

Ketentuan Pasal 42 ayat (1) Undang-Undang Nomor 32 Tahun 2009 tentang Perlindungan dan Pengelolaan Lingkungan Hidup menyatakan bahwa: "Dalam rangka melestarikan fungsi lingkungan hidup, Pemerintah dan Pemerintah Daerah wajib mengembangkan dan menerapkan Instrumen Ekonomi Lingkungan Hidup," menindaklanjuti hal tersebut Peraturan Pemerintah Nomor 46 Tahun 2017 mengelaborasikan secara rinci mengenai Instrumen Ekonomi Lingkungan Hidup.

26 Indonesia, Undang-Undang tentang Pengelolaan Sampah, UU No. 18 Tahun 2008, LN No. 69 Tahun 2008, TLN No. 69, Pasal 4

27 Ibid., Pasal 5

28 Ibid., Pasal 15 
Secara definitif, instrumen ekonomi lingkungan hidup adalah seperangkat kebijakan ekonomi untuk mendorong Pemerintah, pemerintah daerah, atau setiap orang ke arah pelestarian fungsi lingkungan hidup ${ }^{29}$ Instrumen ekonomi lingkungan hidup ini meliputi:

1. Perencanaan pembangunan dan kegiatan ekonomi;

2. Pendanaan lingkungan hidup;

3. Insentif dan/atau disinsentif..$^{30}$

Instrumen Ekonomi Lingkungan Hidup dirumuskan dengan bertujuan untuk menjamin akuntabilitas dan penataan hukum dalam penyelenggaraan perlindungan dan pengelolaan lingkungan hidup, mengubah pola pikir dan perilaku pemangku kepentingan dalam pembangunan dan kegiatan ekonomi, mengupayakan pengelolaan pendanaan lingkungan hidup yang sistematis, teratur, terstruktur, dan terukur, membangun dan mendorong kepercayaan publik dan internasional ${ }^{31}$ dalam pengelolaan Pendanaan Lingkungan Hidup. ${ }^{32}$

Instrumen ini dilaksanakan oleh Pemerintah Pusat dan Pemerintah Daerah untuk menginternalisasikan aspek lingkungan hidup ke dalam perencanaan dan penyelenggaraan pembangunan dan kegiatan ekonomi. Internalisasi Biaya Lingkungan Hidup dilaksanakan dengan memasukkan biaya pencemaran dan/ atau kerusakan lingkungan hidup dalam perhitungan biaya produksi atau biaya suatu Usaha dan/atau Kegiatan. Internalisasi biaya lingkungan hidup dilaksanakan oleh penanggung jawab Usaha dan/atau Kegiatan. ${ }^{33}$

Peran Pemerintah yang pertama dan utama agar sistem pengembalian deposit plastik (plastic deposit refund system) ini dapat berjalan dan dipatuhi adalah dengan menormakan sistem ini melalui peraturan perundang-undangan. Sejatinya UndangUndang Nomor 18 Tahun 2008 tentang Pengelolaan Sampah sudah memiliki semangat yang sama mengenai tanggung jawab produsen dan konsumen plastik

29 Ibid., Pasal 1 angka 33

30 Yang dimaksud dengan "instrumen ekonomi dalam perencanaan pembangunan" adalah upaya internalisasi aspek lingkungan hidup ke dalam perencanaan dan penyelenggaraan pembangunan dan kegiatan ekonomi. Ibid., Penjelasan Pasal 42 Ayat (2) Huruf a

31 Ibid., Pasal 2

32 Ibid., Pasal 3

33 Pasal 2 
untuk melakukan pengelolaan sampah yang baik dan berwawasan lingkungan. Oleh karena itu, substansi hukum yang perlu dibentuk oleh pemerintah untuk mengakomodasi sistem pengembalian deposit plastik adalah dengan membuat Peraturan Pemerintah mengenai Sistem Pengembalian Deposit Plastik sebagai derivasi dari Undang-Undang Nomor 18 Tahun 2008 tentang Pengelolaan Sampah. Peraturan perundang-undangan yang disusun harus dapat mengikutsertakan berbagai pemeran dalam rantai produksi plasti seperti produsen, distributor, pengecer (retailer) serta konsumen apabila take-back dari kemasan-kemasan plastik sekali-pakai dapat diterapkan dengan efektif.

Peran kedua dari pemerintah agar dapat menjalankan sistem pengembalian deposit plastik ini dengan efektif, adalah dalam hal pembangunan infrastrukturinfrastruktur yang dibutuhkan agar pengumpulan plastik ini dapat dijangkau oleh masyarakat. Pemerintah daerah di Indonesia atau pengusaha dapat membangun titik-titik pengumpulan plastik di pusat kota atau tempat ramai penduduk, sehingga masyarakat dapat dengan mudah menjangkau titik pengumpulan ini untuk mengembalikan plastik yang mereka miliki dan langsung mendapatkan uang deposit mereka.

Instrumen ekonomi secara fundamental memperkuat sistem yang bersifat mengatur (regulatory). Pendekatan ini menekankan adanya keuntungan ekonomi bagi penanggung jawab Usaha dan/atau Kegiatan bila menaati persyaratan lingkungan hidup karena antara lain terhindar dari membayar pinalti atau mendapat hukuman, menghemat pengeluaran karena menggunakan praktik efisiensi, dan mendapatkan insentif apabila kegiatannya memberikan dampak positif pada upaya pencegahan kerusakan dan pelestarian lingkungan hidup.

Penerapan instrumen ekonomi sebagai insentif dan disinsentif diibaratkan sebagai koin dengan 2 (dua) sisi mata uang. Kemudahan dan dorongan diberikan ketika terpenuhi ketaatan, dan bahkan besaran insentif dapat terus meningkat sejalan dengan semakin membaiknya kinerja. Sebaliknya, beban dan tambahan kewajiban ditimpakan saat kinerja terus turun dan bahkan terindikasi tidak taat.

Setelah menormakan sistem ini melalui peraturan perundang-undangan, maka substansi hukum yang paling penting untuk dirumuskan oleh pemerintah adalah kontraprestasi atau keuntungan ekonomi bagi penanggung jawab Usaha 
dan/atau Kegiatan bila menaati sistem pengembalian deposit plastik ini. Ada banyak alternatif yang dapat dipilih oleh pemerintah, namun tentu diperlukan kajian mendalam mengenai preferensi dari penanggung jawab Usaha dan/atau Kegiatan di Indonesia agar alternatif yang dipilih nanti dapat ditaati dan dipatuhi secara efektif oleh penanggung jawab Usaha dan/atau Kegiatan.

Implementasi instrumen ekonomi dibutuhkan karena sebagian besar modal alam dan lingkungan hidup, yaitu diantaranya ekosistem dan keanekaragaman hayati, adalah sumber daya milik bersama atau barang publik. Barang publik memiliki karakteristik akses terbuka, seringkali tidak mempunyai pasar formal, dan secara umum dihargai rendah (undervalue). Instrumen ekonomi melalui perencanaan pembangunan dan kegiatan ekonomi diantaranya mengutamakan pendekatan valuasi yang telah memasukkan manfaat ekosistem yang tidak mempunyai pasar atau non market sebagai nilai yang harus diperhitungkan secara riil. Dalam praktiknya, pendekatan seperti ini akan memudahkan penghargaan atas jasa-jasa lingkungan hidup oleh para penggunanya dan terdorong keinginan untuk menjaga keberlanjutannya.

\section{B. Struktur hukum dalam penerapan deposit refund system}

Menurut Undang-Undang Nomor 9 Tahun 2015 tentang Perubahan Kedua atas Undang-Undang Nomor 23 Tahun 2014 tentang Pemerintahan Daerah ada beberapa prinsip otonomi daerah yang digunakan sebagai pedoman dalam pendirian dan penyelenggaraan daerah otonom, yaitu:

1. Sebuah aspek pelaksanaan demokrasi, keadilan, persamaan dan keragaman dan potensi daerah;

2. Pelaksanaan otonomi daerah berdasarkan otonomi, nyata dan bertanggung jawab;

3. Implementasi luas otonomi daerah dan ditempatkan utuh di Kabupaten dan Kota, sedangkan Provinsi adalah otonomi terbatas;

4. Pelaksanaan otonomi daerah harus sesuai dengan konstitusi negara menjamin adanya hubungan yang harmonis antara pemerintah pusat dan daerah serta antar daerah; 
5. Pelaksanaan otonomi daerah harus lebih meningkatkan independensi Daerah Otonom.

Pada prinsipnya, kebijakan otonomi daerah dilakukan dengan mendesentralisasikan kewenangan-kewenangan yang selama ini tersentralisasi ditangan pemerintahan pusat. Dalam proses desentralisasi tersebut, kekuasaan pemerintahan pusat diderivasikan dari tingkat pusat ke pemerintahan daerah sebagaimana mestinya sehingga terwujud pelimpahan kekuasaan dari pusat ke daerah kabupaten dan kota di seluruh Indonesia. Jika dalam kondisi semula arus kekuasaan pemerintahan bergerak dari daerah ke tingkat pusat, maka secara ideal bahwa sejak diterapkan kebijakan otonomi daerah itu, arus dinamika kekuasaan akan bergerak sebaliknya yaitu dari pusat ke daerah. ${ }^{34}$

Sesuai ketentuan Undang-Undang Pemerintahan Daerah, yang dikenal dengan tiga (3) prinsip tata kelola pemerintahan di daerah, yaitu asas desentralisasi, dekonsentrasi, dan tugas pokok. Prinsip Desentralisasi berarti pengalihan kewenangan pemerintah oleh pemerintah ke daerah otonom dalam rangka Negara Kesatuan Republik Indonesia. Dekonsentrasi Prinsip adalah pendelegasian wewenang dari Pemerintah kepada Gubernur sebagai perwakilan pemerintah dan / atau pusat di daerah tersebut, sedangkan Asas Tugas diberikan kepada pemerintah daerah dan desa, dan dari daerah ke desa untuk melaksanakan tugas, bersama dengan dana, sarana dan infrastruktur serta sumber daya manusia hingga pelaksanaan pelaporan wajib dan pertanggungjawaban kepada pihak yang menunjuknya.

Dalam hal pengelolaan sampah di Indonesia, Pemerintah dan pemerintahan daerah bertugas menjamin terselenggaranya pengelolaan sampah yang baik dan berwawasan lingkungan sesuai dengan tujuan Undang-Undang Nomor 18 Tahun 2008 tentang Pengelolaan Sampah. Dalam Pasal 8 UU Pengelolaan Sampah, dalam menyelenggarakan pengelolaan sampah, pemerintahan provinsi mempunyai kewenangan:

1. Menetapkan kebijakan dan strategi dalam pengelolaan sampah sesuai dengan kebijakan Pemerintah;

34 H.M. Busrizalti, Hukum Pemda Otonomi Daerah dan Implikasinya, (Yogyakarta: Total Media, 2013), hlm. 62. 
2. Memfasilitasi kerja sama antardaerah dalam satu provinsi, kemitraan, dan jejaring dalam pengelolaan sampah;

3. Menyelenggarakan koordinasi, pembinaan, dan pengawasan kinerja kabupaten/kota dalam pengelolaan sampah; dan

4. Memfasilitasi penyelesaian perselisihan pengelolaan sampah antar-kabupaten/ antar-kota dalam 1 (satu) provinsi.

Lalu dalam Pasal 9 UU yang sama, pemerintah kabupaten/kota sendiri mempunyai kewenangan:

1. Menetapkan kebijakan dan strategi pengelolaan sampah berdasarkan kebijakan nasional dan provinsi;

2. Menyelenggarakan pengelolaan sampah skala kabupaten/kota sesuai dengan norma, standar, prosedur, dan kriteria yang ditetapkan oleh Pemerintah;

3. Melakukan pembinaan dan pengawasan kinerja pengelolaan sampah yang dilaksanakan oleh pihak lain;

4. Menetapkan lokasi tempat penampungan sementara, tempat pengolahan sampah terpadu, dan/atau tempat pemrosesan akhir sampah;

5. Melakukan pemantauan dan evaluasi secara berkala setiap 6 (enam) bulan selama 20 (dua puluh) tahun terhadap tempat pemrosesan akhir sampah dengan sistem pembuangan terbuka yang telah ditutup; dan

6. Menyusun dan menyelenggarakan sistem tanggap darurat pengelolaan sampah sesuai dengan kewenangannya.

Dapat dilihat bahwa UU Pengelolaan Sampah telah secara jelas mengatur dikotomi kewenangan pengelolaan sampah dengan struktur otonomi daerah, dimana pemerintah provinsi dan pemerintah kabupaten/kota memiliki kewenangan yang lebih luas dalam mengatur pengelolaan sampah di daerahnya masing-masing. UU ini menjadikan pemerintah provinsi dan pemerintah kabupaten/kota sebagai aktor utama dalam menyelesaikan peliknya permasalahan sampah. Guna memperkuat landasan hukum bagi penyelenggaraan pengelolaan sampah di Indonesia, terutama di daerah, maka Kementerian Lingkungan Hidup 
kemudian melahirkan Peraturan Pemerintah Nomor 81 Tahun 2012 tentang Pengelolaan Sampah Rumah Tangga dan Sampah Sejenis Sampah Rumah Tangga. Peraturan Pemerintah ini mengatur secara rinci mengenai kebijakan dan strategi pengelolaan sampah yang setidaknya harus memuat arah kebijakan pengurangan dan penanganan sampah serta program pengurangan dan penanganan sampah. Namun, sedemikian baiknya struktur hukum ini diatur, pengelolaan sampah kota di Indonesia masih menjadi masalah aktual, terutama seiring dengan semakin meningkatnya tingkat pertumbuhan penduduk. ${ }^{35}$

Mekanisme Deposit Refund System dapat menjadi salah satu instrumen ekonomi yang dapat membantu mengurai kusutnya masalah pengelolaan sampah. Agar mekanisme ini dapat diterapkan secara efektif dan efisien, maka sesuai dengan struktur hukum pengelolaan sampah yang sudah dibangun melalui UndangUndang Pengelolaan Sampah beserta dengan peraturan derivatifnya, maka mekanisme Deposit Refund System dapat menjadi bagian yang teralienasikan dari program pengurangan dan penanganan sampah di provinsi dan di kabupaten/ kota seperti yang diamanatkan dalam Pasal 5 Peraturan Pemerintah tentang Pengelolaan Sampah Rumah Tangga dan Sampah Sejenis Sampah Rumah Tangga. Jika belajar dari negara lain seperti Jerman dan Swedia, maka jenis plastik yang dicakup dalam sistem ini adalah Polyethylene Terephthalete Bottle (Botol PET). Botol ini adalah botol plastik yang paling banyak digunakan untuk kemasan air mineral maupun air dengan pemanis, serta botol ini mudah untuk didaur ulang oleh penyelenggara usaha. Botol ini pula yang paling sering ditemukan mengambang di tengah lautan dan samudera dunia.

Pelaksanaan mekanisme Deposit Refund System dalam kerangka otonomi daerah akan membuatnya menjadi mekanisme yang tepat sasaran dan akan lebih mudah dikontrol sesuai dengan daerah kewenangannya masing-masing. Penegakan hukum (law enforcement) terhadap pelanggaran dari kewajiban menerapkan mekanisme Deposit Refund System ini juga akan menjadi lebih efektif jika ditempatkan dalam kewenangan pemerintah provinsi dan pemerintah kabupaten/kota melalui aparat penegak hukum tingkat provinsi dan kabupaten/ kota ketimbang terpusat di Pemerintah Pusat.

35 Rizqi Puteri Mahyudin, “Kajian Permasalahan Pengelolaan Sampah dan Dampak Lingkungan di TPA (Tempat Pemrosesan Akhir)", Jurnal Teknik Lingkungan 3, (2017), hlm. 67. 


\section{Budaya hukum untuk penerapan deposit refund system}

Pengoperasian hukum di masyarakat bergantung pada sikap perilaku masyarakat tersebut. Friedman mejelaskan bahwa suatu legal culture adalah suatu konsep di mana perubahan hukum terjadi karena transformasi sosial yang besar. Dalam hal ini, transformasi sosial yang dimaksud bisa jadi adalah peningkatan kesadaran dan permintaan untuk perlindungan dan reformasi lingkungan. Tuntutan-tuntutan untuk perubahan tersebut diklasifikasikan oleh Friedman sebagai bagian dari hukum "eksternal" yang merupakan pendapat, minat, dan tekanan oleh masyarakat yang dapat membentuk hukum. Opini dan dorongan masyarakat tersebut dapat membangun jalan bagi Total Justice yang pada saat yang bersamaan menghasilkan perubahan sosial. ${ }^{36}$ Pengakuan pada legal culture intinya mengenal bahwa keberlakuan hukum tidak semata-mata bergantung pada efektivitas suatu perangkat peraturan perundang-undangan (law on the books) namun juga hukum yang hidup (law in action). ${ }^{37}$ Terkait dengan pembahasan mengenai sistem pengembalian dana deposit, efektivitas penerapan deposit-refund system tidak hanya bergantung pada intervensi pemerintah melalui berbagai bentuk peraturan perundang-undangan, namun juga pada seberapa baik pihak-pihak lain yang berperan sepanjang rantai produksi kemasan plastik menginternalisasi pentingnya upaya pengumpulan kembali sampah plastik. Masyarakat harus mawas akan keberlanjutan lingkungan. Pihak-pihak yang terletak pada sisi produksi, distribusi, dan koleksi pada rantai produksi harus menyadari bahwa inisiatif ini tidak hanya menguntungkan bagi masyarakat dan keberlanjutan lingkungan namun juga bagi kegiatan usaha mereka. Walaupun munculnya budaya tersebut bisa dicetuskan oleh penekanan terhadap insentif ekonomi berupa refund, namun ke depannya jika pengaturan deposit refund system diharapkan untuk langgeng, maka perlu pembentukan budaya yang berkelanjutan pula melalui pendidikan dan sosialisasi melalui sekolah-sekolah dan kepada unit-unit masyarakat terkecil seperti Rukun Tetangga untuk mengasah tingkat kepekaan masyarakat terhadap masalah plastik di lingkungan.

36 David Nelken, 2004 “Using the Concept of Legal Culture," Australian Journal of Legal Philosophy, Vol. 29, hlm. 9

37 Susan S. SIlbey, "Legal culture and cultures of legality," Handbook of Cultural Sociology, July 2010, hlm. 471 


\section{Kesimpulan}

Jika Indonesia tidak bergerak dengan cepat untuk menyelesaikan permasalahan plastik kronis yang melanda perairannya secara progresif dan komprehensif, kesehatan lingkungan perairan Indonesian akan terancam oleh pencemaran plastik yang dilanggengkan oleh rakyatnya sendiri sebagai produsen dan konsumen bahan praktis dan populer tersebut.

Penanganannya plastik di perairan Indonesia sudah tidak bisa bergantung pada penegakan hukum lingkungan yang eksklusif berada di tangan pemerintah dalam bentuk atur dan awasi. Pemerintah sebagai pembuat kebijakan sudah seharusnya melirik inisiatif-inisiatif instrumen ekonomi agar pelaku ekonomi pengguna dan pembuat plastik dapat menginternalisasi biaya-biaya pencemaran sebagai suatu eksternalitas kembali ke dalam biaya produksi dan pemakaian.

Deposit refund system adalah suatu mekanisme ekonomi lingkungan di mana seseorang harus membayar di muka sejumlah uang untuk menjamin bahwa ia tidak akan melakukan pencemaran atau bahwa dia akan melakukan suatu kewajiban. Dengan kaitannya dalam penanggulangan pencemaran plastik fungsinya adalah untuk memfasilitasi pengembalian produk. Sebagai salah satu bentuk dari instrumen ekonomi dalam penaatan hukum lingkungan adalah manifestasi dari penerapan prinsip pencemar membayar, namun apabila sistem tersebut diharapkan dapat mengubah harus dijamin adanya suatu sistem legal system yang efektif pula. Menurut Friedman, sistem hukum yang efektif harus memiliki tiga komponen yaitu adanya substansi hukum, struktur hukum, dan budaya hukum yang mendukung penaatan hukum yang ada.

Dari segi substansi, Indonesia sendiri sudah mempunyai landasan-landasan penerapan deposit refund system dengan adanya Undang-Undang Nomor 32 Tahun 2009 tentang Perlindungan dan Pengelolaan Lingkungan Hidup, Undang-Undang Nomor 18 Tahun 2008 tentang Pengelolaan Sampah, Peraturan Pemerintah Nomor 46 Tahun 2017 tentang Instrumen Ekonomi Lingkungan Hidup, dan Peraturan Pemerintah Nomor 81 Tahun 2012 tentang Pengelolaan Sampah Rumah Tangga dan Sampah Sejenis Sampah Rumah Tangga. Namun substansi yang lebih spesifik mengenai sistem tersebut harus ditetapkan agar program deposit refund tidak hanya menjadi suatu wacana yang tidak mempunyai pengaturan normatif. 
Komponen struktur yang penting bagi penerapan deposit refund system adalah pembagian kewenangan daerah dan pembangunan infrastruktur yang dibutuhkan pada unit terkecil yang dapat dijangkau oleh masyarakat agar product take-back kemasan-kemasan plastik dapat terlaksana. Namun, selain fondasi normatif dan fasilitas, harus ada elemen budaya masyarakat jika mekanisme tersebut diharapkan memiliki keberlanjutan. Patut dicatat bahwa budaya masyarakat sendiri dapat dibentuk dan diubah oleh kebiasaan-kebiasaan sosial baru jika memang itu yang dibutuhkan untuk melanggengkan kesehatan lingkungan.

Indonesia sudah tidak mempunyai hak istimewa untuk mengabaikan keberadaan sampah-sampah plastik di perairan yang menjadi konsekuensi dari tingkat konsumsi bahan serba guna tersebut. Suatu non-traditional threat terhadap pemberi kehidupan bangsa kita harus dihadapi dengan solusi yang non-traditional pula, sehingga diharapkan bahwa penerapan deposit refund system dapat menjadi suatu solusi yang progresif, tepat guna dan kolaboratif untuk memecahkan polemik plastik Indonesia. 


\section{Daftar Pustaka}

Amelia Hastuti, “Tragedi Longsor TPA Leuwigajah Harus Jadi Cambuk bagi Masyarakat Agar Peduli Sampah", http://rri.co.id/post/berita/363673/feature/tragedi_longsor_tpa_leuwigajah_harus_jadi_cambuk_bagi_masyarakat_agar_peduli_sampah.html

Anker Andersen, "Deposit system law- Germany," http://anker-andersen.dk/ deposit-laws/germany.aspx

Busrizalti, H.M. 2013. Hukum Pemda Otonomi Daerah dan Implikasinya. Yogyakarta: Total Media.

Departemen Kelautan dan Perikanan Sekretaris Jendera Satuan Kerja Dewan Maritim Indonesia. 2008. Evaluasi Kebijakan dalam Rangka Implementasi Konvensi Hukum Laut Internasional (UNCLOS 1982) di Indonesia. Jakarta: DKP.

DPG-Pfandsystem, "Function of the Deposit-Scheme," http://www.dpgpfandsystem.de/index.php/en/.

Friedman, Lawrence M. 1975. The Legal System: A Social Science Perspectiv., New York: Russel Sage Foundation.

Hotta, Yasuhiko, et.al., eds. 2009. Extended Producer Responsibility Policy in East Asia: in Consideration of International Resource Circulation. Japan: Institute for Global Environmental Strategies.

Indonesia, Undang-Undang tentang Pengelolaan Sampah, UU No. 18 Tahun 2008, LN No. 69 Tahun 2008, TLN No. 69, Pasal 4.

Ivan, “Sampah plastik diprediksi penuhi lautan pada 2050”, https:// beritagar.id/ artikel/sains-tekno/sampah-plastik-diprediksi-penuhi-lautan-pada-2050.

Jambeck, J.R., Andrady, A., Geyer, R., Narayan, R., Perryman, M., Siegler, T., Wilcox, C., Lavender Law, K. 2015. "Plastik waste inputs from land into the ocean", Science, 347.

Jimly Asshidiqie, "Demokrasi dan Ekokrasi”, http://www.jimly.com/makalah/ namafile/160/Demokrasi_dan_Ekokrasi.pdf 
Kementerian Lingkungan Hidup dan Kehutanan, Surat Edaran tentang Pelaksanaan Peringatan Hari Peduli Sampah Nasional (HPSN) Tahun 2017, Surat Edaran Nomor SE.1/MenLHK-SetJen/Rokum/PLB.3/1/2017.

Mahyudin, Rizqi Puteri. 2017. “Kajian Permasalahan Pengelolaan Sampah dan Dampak Lingkungan di TPA (Tempat Pemrosesan Akhir)", Jurnal Teknik Lingkungan 3.

Nelken, David. 2004. "Using the Concept of Legal Culture," Australian Journal of Legal Philosophy, Vol. 29.

OECD, Extended Producer Responsibility: Guidance for efficient waste management, (Paris: OECD Pubishing, 2016),

Orts, Eric W. 1995. “A Reflexive Model of Environmental Regulation, “Business Ethics Quarterly", Vol. 5(4).

Orts, Eric W. 1995. “Reflexive Environmental Law, “Northwestern University Law Review", Vol. 89.

Pindyck, Robert S. dan Daniel L. Rubinfeld. 2001. Microeconomics. Prentice Hall.

Purwaeni, Hartuti. “Bom Waktu Sampah”, Suara Merdeka (Februari 2017).

Silbey, Susan S. 2010. "Legal culture and cultures of legality," Handbook of Cultural Sociology.

Tahir, Akbar. s.n. "Anthropogenic Debris in Seafood", Departemen Ilmu Kelautan Fakultas Ilmu Kelautan dan Perikanan Universitas Hasanuddin.

Undang-Undang Dasar Negara Republik Indonesia Tahun 1945, Pasal 28H ayat (1) Wibisana, Andri G. 2017. “Campur Tangan Pemerintah Dalam Pengelolaan Lingkungan: Sebuah Penelusuran Teoretis Berdasarkan Analisis Ekonomi atas Hukum (Economic Analysis of Law), Jurnal Hukum \& Pembangunan 47 No. 2.

World Economic Forum. 2016. “The New Plastics Economy: Rethinking the future of plastics", World Economic Forum.

Zero Waste Europe, "Beverage packaging and Zero Waste," https://www. zerowasteeurope.eu/tag/germany-deposit-refund-system/. 